\title{
A study of the fatty acid and tocochromanol patterns of some Fabaceae (Leguminosae) plants from Turkey I
}

\author{
By Eyup Bagci*(1), Ludger Bruehl (2), Hasan Özçelik (3), Kurt Aitzetmuller (2), \\ Mecit Vural (4) and Ahmet Şahim (1)
}

\author{
${ }^{1}$ Firat University, Science \& Letter Faculty, Biology Department, Elazig-Turkey. \\ E-mail: ebagci@firat.edu.tr \\ ${ }^{2}$ Inst. for Chemistry and Physics of Lipids, BAGKF, Piusallee 76, Muenster-Germany. \\ ${ }^{3}$ Süleyman Demirel University, Science \& Letter Fac., Biology Deprt. Isparta- Turkey. \\ ${ }^{4}$ Gazi Univ. Science Faculty, Biology Deprt., Ankara - Turkey.
}

\section{RESUMEN}

Un estudio de los patrones de ácidos grasos y tococromanoles de algunas plantas Fabaceae (Leguminosae) de Turquía.

En este estudio, los contenidos en ácidos grasos, tocoferoles, tocotrienoles y plastocromanol-8 de algunas especies seleccionadas de Fabaceae (Leguminosae), pertenecientes a diferentes géneros (Colutea, Vicia, Lathyrus, Gonocytisus, Lupinus, Hedysarum, Onobrychis, Trigonella) de Turquía, fueron determinadas usando técnicas de GLC y HPLC. Algunas de las especies estudiadas son endémicas de Turquía. Los aceites de semillas de los diferentes taxones de leguminosas contenían los ácidos linoleico, oleico y linolénico como principales componentes. Las proporciones de estos ácidos grasos fueron muy variables entre los géneros de leguminosas. Los ácidos palmítico y esteárico son los principales ácidos grasos saturados en los aceites de semillas. Los patrones de Vicia y Onobrychis mostraron una alta similitud en las medias de las concentraciones de ácidos grasos cualitativos. Los patrones de tocoferoles y tococromanoles en los aceites de semillas resultaron también ser altamente variables entre los géneros investigados aquí. El total de tocoferoles fue superior al de tocotrienoles. Los tocoferoles alfa y gamma fueron los principales tocoferoles encontrados en el conjunto de especies. Los tocotrienoles beta, gamma y delta no se encontraron en la mayoría de los patrones estudiados de leguminosas. Los resultados son discutidos con vistas a los recursos renovables y a la quimiotaxonomía..

PALABRAS-CLAVE: : Ácidos grasos - Fabaceae (Leguminosae) - Quimiotaxonomía -Tococromanoles.

\section{SUMMARY}

A study of the fatty acid and tocochromanol patterns of some Fabaceae (Leguminosae) plants from Turkey I.

In this study, the fatty acid, tocopherol, tocotrienol and plastochromanol-8 contents of some selected Fabaceae (Leguminosae) species belonging to different genera (Colutea, Vicia, Lathyrus, Gonocytisus, Lupinus, Hedysarum, Onobrychis, Trigonella) from Turkey were determined by using GLC and HPLC techniques. Some of the studied species are endemic to Turkey. The seed oils of different Leguminous taxa contained linoleic, oleic and linolenic acids as their major components. The ratios of these fatty acids in the Leguminous genera were found to be highly variable. Palmitic and stearic acids are the major saturated fatty acids in the seed oils. Vicia and Onobrychis patterns showed high similarity in means of qualitative fatty acid concentration. The tocopherol and tocochromanol patterns of the seed oils were also found to be highly variable among the genera investigated here. The total tocopherols was higher than the total tocotrienols. Alpha and gamma tocopherols were also the highest tocopherols present in the whole species. Beta, gamma and delta-tocotrienols were not found in most of the studied leguminous patterns. The results are discussed in view of renewable sources and chemotaxonomy.

KEY-WORDS: Chemotaxonomy - Fabaceae (Leguminosae) - Fatty acids - Tocochromanols,.

\section{INTRODUCTION}

The Fabaceae (Leguminosae) is a family of flowering plants comprising about 269 genera and 5100 species (Mabberley, 1997) and it is one of the largest plant families in Turkey and in the world. It has 68 genera and more than 900 species in Flora of Turkey (Davis, 1970, 1988; Seçmen et al., 1989). The family is important as food plants, especially leguminate (beans, gram, peas), oil (soybean, ground nut), but also for tanbarks, timber, copal, gums, insecticides and cultivated ornamentals, as well as medicinal plants (Seçmen et al., 1989; Tsevegsuren et al., 1998).

Leguminosae is well suited with respect to chemical components. Lipids from some more common Leguminosae have been investigated to some extent, other legume lipids have not been studied in any great detail because of their low lipid content and limited or negligible use for oil purposes (Gunstone et al., 1972; Kleiman, 1988; Chowdurry, 1984, 1986, 1995; Ucciani, 1995; Grela and Gunter, 1995). Some species of the family Fabaceae (Leguminosae) are also sources of cheap protein for both humans and animals (Tewatia and Wirk, 1996).

Omega 3- fatty acids are polyunsaturated fatty acids which have been associated with many health benefits (Freeman, 2000). Linoleic acid is needed for a normal immune response and an essential fatty acid deficiency impairs $B$ and $T$ cell-mediated responses (Meydani et al., 1991). Tocopherols naturally present in seeds have been strongly 
correlated with the polyunsaturated fatty acids since they counteract the potential oxidative stress caused by fats in the diet (Anttolainen et al., 1995).

Seed oils with a substantial amount of very long chain FAs have attracted attention because of their value for industrial purposes. Furthermore these compounds can be of chemotaxonomic significance (Bagci et al., 2003). The fatty acid and tocopherol composition of plant seed oils can provide characteristic information in order to confirm taxonomical and phylogenetic relationships in the plant kingdom (Goffman et al., 1999; Bagci et al., 2004). Relatively complete data on the fatty acid composition of seed oils from Leguminosae were first used for chemotaxonomic consideration by Wolff and Kwolek, (1971).

In this study, the fatty acid, tocopherol, tocotrienol and plastochromanol content of some selected plant samples from different genera (Gonocytisus Spach., Lupinus L., Colutea L., Vicia L., Lathyrus L., Hedysarum L. Onobrychis Adans., Hedysarum L., Trigonella L.) of Fabaceae from Turkey were investigated. Among these taxa, Colutea melanocalyx, Vicia freyniana Bornm., Trigonella cretica (L.) Boiss., Hedysarum cappadocicum Boiss., Onobrychis huetiana Boiss., Gonocytisus dirmilensis Hub.-Mor. are endemic to Turkey (Davis, 1970). There are a few reports on the Turkish Fabaceae (Bagci and Vural, 2001, Akpinar et al, 2001; Azcan et al., 2001; Bagci et al., 2001, Bagci and Sahin 2004). The study on the fatty acid and tocopherols of some genera from Fabaceae was found to be of interest and fatty acid and tocochromanol contents of these genera might provide new information and some contributions on the chemotaxonomic relationships of some Fabaceae genera.

\section{MATERIAL AND METHODS}

\subsection{Plant samples}

Some seed specimens were collected in natural habitats from different regions of Turkey and some of the samples were obtained from the seed bank in Aegean Agricultural Research Institute, Izmir. Studied plant samples from different genera are listed in Table I.

\subsection{Chemical Analysis}

\subsubsection{Oil Extraction and preparation of fatty acid methyl esters (FAME)}

Impurities were removed from the seeds and the cleaned seeds were ground into powder using a ball mill. Lipids were extracted with heptane in a straight through extractor. The triglycerides were transesterified to methyl esters with potassium hydroxide in methanol according to ISO method 5509 (1989).

\subsubsection{Capillary GLC}

The fatty acid methyl ester composition was determined on three different gas chromatographs, Hewlett-Packard HP5890 (A), HP6890 (B) and Unicam - $610(\mathrm{C})$ each equipped with a fused silica WCOT capillary and FID:

A) Silar 5 CP, 50 m. x $0.25 \mathrm{~mm}$ ID, $0.24 \mathrm{~m}$ film thickness, nitrogen as carrier gas, 1:50 split ratio, pressure $160 \mathrm{kPa}$, oven temp.: $5 \mathrm{~min}$ isothermal at $163{ }^{\circ} \mathrm{C}$, then 163 to $205^{\circ} \mathrm{C}$ at $1{ }^{\circ} \mathrm{C} / \mathrm{min}$; Inj. $=230{ }^{\circ} \mathrm{C}$, Det. $260^{\circ} \mathrm{C}$.

B) DB-23, $60 \mathrm{~m} \times 0.32 \mathrm{~m}(\mathrm{~J} \& \mathrm{~W}), 0.25 \mathrm{~m}$ film thickness, hydrogen as carrier gas, 1:50 split ratio, pressure $69 \mathrm{kPa}$, , oven temp.: $1 \mathrm{~min}$ isothermal at $80^{\circ} \mathrm{C}$, then 80 to $150{ }^{\circ} \mathrm{C}$ at $25^{\circ} \mathrm{C} / \mathrm{min}$ than 150 to $240{ }^{\circ} \mathrm{C}$ at $3{ }^{\circ} \mathrm{C} / \mathrm{min}, 5 \mathrm{~min}$ isothermal, PTV-Inj. $80{ }^{\circ} \mathrm{C}, 12{ }^{\circ} \mathrm{C} / \mathrm{s}$ to $250{ }^{\circ} \mathrm{C}, 5 \mathrm{~min}$ isothermal, Det. $250{ }^{\circ} \mathrm{C}$.

C) $\mathrm{BPX}-70,15 \mathrm{~m} \times 0.32 \mathrm{~mm}$. carrier gas; $\mathrm{N}, \mathrm{ml}$ /min- 2.5, hydrogen as carrier gas, 1:40 split ratio, oven temp.: $1 \mathrm{~min}$ isothermal at $80{ }^{\circ} \mathrm{C}$, then 80 to $185^{\circ} \mathrm{C}$ at $5{ }^{\circ} \mathrm{C} / \mathrm{min}, 3-5 \mathrm{~min}$ isothermal, PTV-Inj. $80^{\circ} \mathrm{C}, 5^{\circ} \mathrm{C} / \mathrm{s}$ to $185^{\circ} \mathrm{C}, 11 \mathrm{~min}$ isothermal, Det. 210 ${ }^{\circ} \mathrm{C}$.

Data analysis was done with a chromatointegrator D 2500 (Merck-Hitachi) and a Chemstation integration software, respectively. Peak identification was achieved by comparison of relative retention times with those obtained from test mixtures of known composition on three different columns.

\subsubsection{Tocopherol analysis}

Tocochromanols were determined by highperformance liquid chromatography (HPLC) according to the procedure of Balz et al. (1992). An aliquot of a solution of $50 \mathrm{mg}$ oil in $1 \mathrm{ml}$ heptane was injected into an HPLC system via a Rheodyne valve with a sample loop volume of $20 \mu \mathrm{l}$. Tocopherols were separated on a LiChrospher 100 Diol phase, $5 \mathrm{~m}$ particle size (Merck, Darmstadt, Germany). HPLC column $25 \mathrm{~cm} \times 4.6 \mathrm{~mm}$ ID with an additional guard column $4 \mathrm{~mm}$ long and $4 \mathrm{~mm}$ ID, filled with LiChrospher Si 60, $5 \mu \mathrm{m}$ particle size. The system was operated with an eluent of heptane/tert.-butyl methyl ether $(96+4 \mathrm{v} / \mathrm{v})$ and detection by a fluorescence detector F-1000 (Merck, Darmstadt) at 295 nanometer excitation wavelength and $330 \mathrm{~nm}$ emission wavelength. A D-2500 Chromato Integrator (Merck, Darmstadt) was used for data acquisition and processing. Calibration was done by external standards with $\alpha$-, $\beta-, \gamma$ - and $\delta$-tocopherol (Calbiochem, Bad Soden, Germany). Tocotrienols are calculated with the same response factors as the corresponding tocopherols and plastochromanol-8 was calculated with the same response factor as gamma-tocopherol (Balz et al., 1992). 


\section{RESULTS AND DISCUSSION}

In this study, the fatty acid and tocochromanol compositions of the seeds of some selected Fabaceae species from Turkey were determined. The results of the fatty acid analysis and the oil yield of the taxa belonging to Gonocytisus, Lupinus, Colutea, Vicia, Lathyrus, Hedysarum, Onobrychis and Trigonella genera (totally 17 taxa) are shown in Table I; the tocopherol and tocotrienol contents of the studied taxa are shown in Table II Vicia, Lathyrus, Trigonella and Onobrychis genera have the highest taxa number in Flora of Turkey in family Fabaceae (Davis, 1970; 1988)

The total lipid of the studied leguminous species were found between $18.7 \%$ and $32.3 \%$ (Vicia canescens subsp. latistipatula and Trigonella cretica, respectively) (Table I). The oil contents of the studied legumes belonging to different genera showed significant quantitative differences. Although qualitative differences were also found, the fatty acid patterns of the studied leguminous taxa belonging to different genera showed uniform fatty acid (FA) composition.

Analysis showed that low molecular acids (lauric, myristic, pentadecanoic acids) from the saturated fatty acid (SFA) were absent or present at trace levels in the Leguminosae seed oils. Palmitic acid (16:0) was the highest SFA in Trigonella cretica (12.9\%), Lupinus varius (12.8\%) and Colutea melanocalyx (10.7\%) respectively. This is also a very constant lipid constituent in most of the Leguminous genera seed oils. It is possible to say that this fatty acid is not a highly variable component in the leguminous genera pattern. 16:1, 16:2, Margaric $(17: 0)$ and margaroleic (17:1) acids were not detected or in very small amounts (Table I).

Stearic acid (18:0) was generally found in a low level. But Onobrychis hypargyrea (4.20\%), Vicia cappadocica (3.91\%), Lupinus (3.77\%) and Trigonella $(3.63 \%)$ patterns were shown in higher concentrations. This is also reported for some Vicia sp. from Turkey like $V$. hyrcanica Fisch. et Mey., $V$. peregrina L. (7.3\%), V. hybrida L. (9.1\%) (Akpinar et al., 2001). On the other hand, this fatty acid was reported as lower in some Vicia sp. from different countries; Vicia faba (1.4\%), V. sativa (1.3\%). Colutea melanocalyx and Onobrychis altissima (1.38\% and $1.79 \%$ ) seed oils showed low stearic acid amounts. This FA was reported as $3.1 \%$ in Colutea arborescens (Ivanov \& Aitzetmuller, Unpublished).

The other SFA of the legume seed oils (20:0 and 24:0, arachidic and lignoceric acid) in the studied species, were shown to be lower than $1 \%$ except $V$. cappadocica and Trigonella cretica. But 22:0 (Behenic acid) was different from these FA in the studied genera patterns. Trigonella, Lathyrus laxiflorus, Onobrychis major, two subspecies of $V$. canescens and Hedysarum species contained this
FA in more than 1\%. Some researchers indicated that oils with high levels of long chain SFA such as behenic acid may be difficult for the digesting enzymes in humans and animals (Hilditch et al., 1964; Balogun and Fetuga, 1985; Akpinar et al., 2001).

Among the unsaturated fatty acids (USFA), oleic and linoleic acid were the major constituents of the studied legume seed oil. The highest percentages of oleic acid was determined in Trigonella cretica (46.9\%), Onobrychis hypargyrea (34.4\%) and Lathyrus laxiflorus subsp. laxiflorus (30.4\%) respectively (Table I). On the other hand, Vicia michauxii var. stenophylla (12.3\%), Colutea melanocalyx (12.7\%), Gonocytisus dirmilensis (13.19\%) and Onobrychis huetiana (13.3\%) showed the lowest oleic acid composition in the seed oils. Linoleic acid was determined as the major constituent of all the seed oils except Trigonella cretica. This fatty acid comprized more than half of the seed oil in Colutea melanocalyx (62.8\%), Gonocytisus dirmilensis $(67.4 \%)$, Lupinus varius (57.8\%), Vicia cappadocica (50.9\%) and Onobrychis major (51.7\%). A high content of this component was found to be characteristic for the legume seed oil. Vicia patterns show a wide variation in this component and it was also found in small amounts in Trigonella, Vicia michauxii var. stenophylla (Table I). The seed oils of all the investigated species were richer in oleic and linoleic acid than in linolenic acid. In the Akpinar et al. (2001) study, while most of the studied Vicia samples showed this result, Vicia hybrida contrasted from the other Vicia taxa. At the same time, oleic and linoleic acids were determined to be the major unsaturated fatty acid in Psophocarpus tetragonolobus (L.) (Fabaceae) DC. (winged bean) oil which is used as a food in the nutrition of some countries (Higuchi et al., 1982).

Linolenic acid (18:3) in the legume seed oils was generally found to be lower than $10 \%$, except in a few taxa like Hedysarum cappadocicum (21.1\%), Vicia michauxii var. michauxii (39.1), two Lathyrus taxa $(16.5-17.9 \%)$ and Onobrychis huetiana (18.3\%) and O. major $(11.2 \%)$. In the others, it was generally lower than ten percent of the oil. This fatty acid was the most variable component among the leguminous genera when compared with the other constituents.

Total saturated fatty acid (TSFA) levels of the studied legume seed oils did not show variation between genera except in the Lupinus (17.36) and Trigonella (21.5\%) patterns. These two samples had high saturated FA compositions when compared with the others. On the other hand Lathyrus laxiflorus $(6.2 \%)$ and Onobrychis huetiana $(7.9 \%)$ samples were proven to have a very low concentration of TSFA in the oils. It is possible to say that the total saturated fatty acid content of the legume seed oils is between $10-20 \%$. TUSFA composition of the seed 


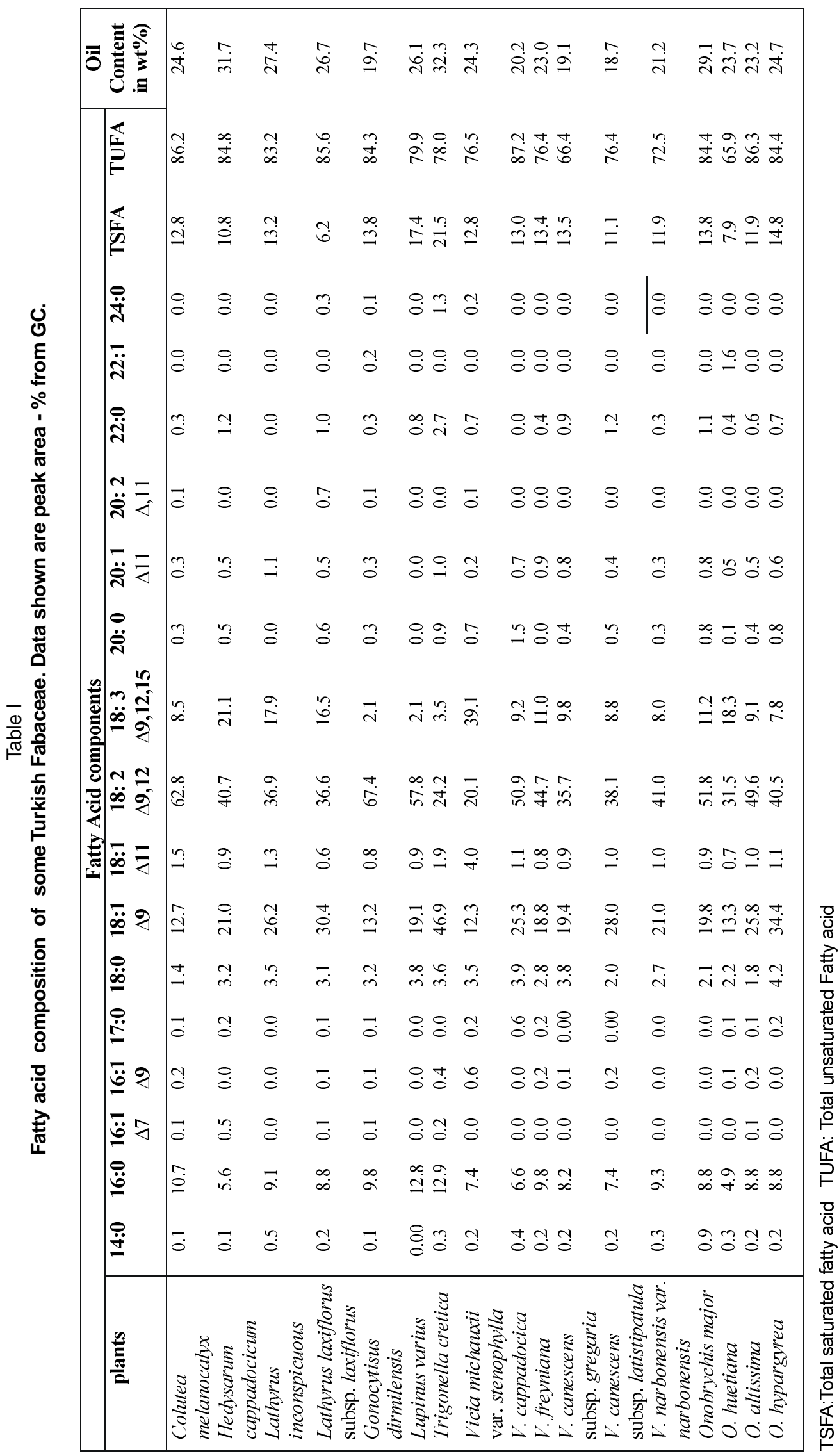


oils is generally between $75-90 \%$ in the oil for most of the studied specimens. But Vicia patterns and Onobrychis huetiana containied lower than 70\% TUFA (Table I).

Erucic acid (22:1) has undesirable effects on the metabolisms of animals and humans (Baudet, 1976; Feil and Stamp, 1993; James, 1994). But it is not detected in most of the legume seed oils except Gonocytisus dirmilensis (0.2\%) and Onobrychis huetiana (1.6\%). Garcia-Lopez et al. (2001) reported that some Lupinus sp. oils contained high concentrations of palmitic and linoleic acid and that erucic acid was not reported in any of the lupin oils analyzed while eicosanoic acid (22:0) was found only in Lupinus mexicanus. Some Lupinus seed oils (Lupinus albus L., L. angustifolius L., L. Iuteus L., and L. mutabilis Sweet. (lupin oil, Tarwi seed oil) are reported as oil plants in the world (Aitzetmuller, 1997).

The seed oils of the leguminous species contained very low levels of monoenoic fatty acids which were lower than polyenoic FA. (Table I). This is important for the quality of oils consumed as a food resource.

The results of the present study, as far as unsaturated fatty acid content is concerned, are supported by previous Leguminous studies (Sengupta and Basu, 1978; Daulatab et al., 1987; Tharib and Veitch, 1983; Hamberg and Fahlstadius, 1992; Liu et al., 1995). All these studies showed that the saturated and particularly unsaturated FA contents of Fabaceae seed oils are closely allied to each other and that the main components in the oils are linoleic-oleic type fatty acids.

Tocopherols, together with tocotrienols and plastoquinones, are known as tocochromanols (Seher and Ivanov, 1973; Velasco et al., 2000) and some of them exhibit vitamin $E$ activity. With this study some Turkish leguminous seed oils were examined as potential sources of natural tocopherols and tocotrienols. The tocochromanol (tocopherol and tocotrienol) derivatives $\alpha, \beta, \gamma$ and $\delta$-tocopherols and tocotrienols and 8-plastochromanol were detected in some of the studied Fabaceae seed oils (Table II). $\alpha$ and $\gamma$-tocopherol were detected as the most abundant tocopherol components in all of the studied taxa except Lathyrus inconspicuus, Onobrychis huetiana, and $O$. hypargyrea. This is also reported for some Fabaceae taxa from Bulgarian Flora (Arachis hypogaea, Gleditsia triacanthos, and Robinia pseudoacacia) (Ivanov and Aitzetmuller, 1998). Colutea and Trigonella species had the highest tocopherol level (85.7 and $89.4 \%$ respectively) in all of the studied taxa. On the other hand, Hedysarum cappadocicum (69.9\%), Vicia michauxii var. stenophylla $(80.2 \%)$, V. cappadocica $(93.4 \%)$, and in general Onobrychis species (except $O$. huetiana and $O$. hypargyrea) were characterized by the high content of gamma tocopherol in each oil (Table II). tocopherol was determined in the Lathyrus inconspicuus(51.7\%), L. laxiflorus subsp. laxiflorus $(46.7 \%)$ and 0 . huetiana (34.3\%) at a high level, but it was not detected in most of the others (Table II). Onobrychis genera patterns showed the highest fatty acid and tocochromanol variability in the studied Leguminosae. This requires further investigation in view of both fatty acid and vitamin resources as well as chemotaxonomic relationships.

The tocochromanol analysis of the Fabaceae seed oils from Turkey showed that they contained low percentages of tocotrienols. The highest - tocotrienol was found in Onobrychis hypargyrea (65.6\%), Lupinus varius (45.9\%) and Gonocytisus dirmilensis $(23.3 \%)$ and the other taxa had lower than $10 \%$. Other tocotrienols were either not found or determined in very small amounts. Plastochromanol -8- was found in trace amounts in most of the studied species, except two Lathyrus taxa (Table II). The analysis results showed that the total tocopherol content of the studied Fabaceae species was higher than the total tocotrienol level (Table II). On the other hand, there are some clues on the variation of the tocochromanols in family patterns. Lupinus, Gonocytisus and Onobrychis genera were demonstrated to have different tocopherol and tocotrienol patterns in means of individual and total amounts compared to other genera. It can be possible to differentiate the taxa in the following groups: 1) Having high - tocopherol, like Colutea and Trigonella patterns. 2) Having high $\gamma$ - tocopherol, as in Hedysarum, Vicia and some Onobrychis patterns.

It is determined that linoleic and oleic acid are abundant components in most of the leguminous genera and this may be a characteristic of the family or of some genera. But some results showed that the linoleic - palmitic type FA pattern is typical for some genera like Cassia nodosa, Berlinia auriculata, Bauhinia monandra, Parkia clappertoniana (Balogun and Fetuga, 1985), some Astragalus sp (Bagci and Vural, 2001), some Ebenus species reported from Turkey (Azcan et al., 2001) or linoleic - oleic - palmitic type, like in some Lathyrus species (Bagci et al., 2001; Bagci and Sahin, 2004) and some Crolataria species (Fabaceae) (Chowdury and Banerjii, 1995). The seed oils of all leguminous members contained very low levels of linolenic acid, both in this study and in reports from the literature, cited above (Hemavathy and Prabhakar, 1989).

Such a favourable composition of USFA in most of the legume seed oils suggests that some of these species may have potential as renewable sources in oilseed crop for the food and oil industry, if growth and different regional yields can be improved. The present study shows the infrafamilial variability for fatty acid and tocochromanols in Fabaceae. With this study, it was confirmed that patterns of fatty acids 
Table II

Tocochromanol composition of Some Turkish Fabaceae. Data shown are peak area - \% from HPLC

\begin{tabular}{|c|c|c|c|c|c|c|c|c|c|c|c|}
\hline \multirow[t]{2}{*}{ plants } & \multicolumn{11}{|c|}{ Tocochromanols } \\
\hline & $\alpha-\mathbf{T}$ & $\beta-\mathbf{T}$ & $\gamma-\mathbf{T}$ & $\delta-\mathbf{T}$ & $\alpha-\mathbf{T}_{3}$ & $\beta-\mathbf{T}_{3}$ & $\gamma-\mathbf{T}_{3}$ & $\delta-\mathbf{T}_{\mathbf{3}}$ & P-8 & TToc & $\mathbf{T T}_{\mathbf{3}}$ \\
\hline Colutea melanocalyx & 85.7 & 0.5 & 11.3 & 0.6 & 1.4 & 0.0 & 0.0 & 0.0 & 0.5 & 98.1 & 1.4 \\
\hline Hedysarum cappadocicum & 27.2 & 0.4 & 69.9 & 0.6 & 0.3 & 0.0 & 0.6 & 0.4 & 0.6 & 98.2 & 1.2 \\
\hline Lathyrus inconspicuus & 38.7 & 51.7 & 3.9 & 1.6 & 1.8 & 0.0 & 0.0 & 0.0 & 2.2 & 96.0 & 1.8 \\
\hline $\begin{array}{l}\text { Lathyrus laxiflorus subsp. } \\
\text { laxiflorus }\end{array}$ & 44.7 & 46.7 & 2.5 & 1.0 & 2.0 & 0.0 & 0.0 & 0.0 & 3.1 & 94.9 & 2.0 \\
\hline Gonocystis dirmilensis & 31.7 & 2.8 & 31.8 & 4.0 & 23.3 & 0.0 & 1.5 & 4.9 & 0.0 & 70.3 & 29.7 \\
\hline Lupinus varius & 41.9 & 0.0 & 12.3 & 0.0 & 45.9 & 2.0 & 0.0 & 0.0 & 0.0 & 54.2 & 45.9 \\
\hline Trigonella cretica & 89.4 & 0.3 & 8.4 & 0.4 & 0.0 & 0.0 & 0.0 & 0.0 & 0.8 & 98.5 & 0.0 \\
\hline $\begin{array}{l}\text { Vicia michauxii var. } \\
\text { stenophylla }\end{array}$ & 2.0 & 0.1 & 80.2 & 10.6 & 3.1 & 1.9 & 0.6 & 0.0 & 0.0 & 92.9 & 5.6 \\
\hline$V$. cappadocica & 3.8 & 0.0 & 93.4 & 1.5 & 0.0 & 0.0 & 0.3 & 0.0 & 1.0 & 98.7 & 0.3 \\
\hline Onobrychis major & 1.3 & 0.1 & 77.2 & 20.9 & 0.0 & 0.0 & 0.2 & 0.1 & 0.3 & 99.7 & 0.3 \\
\hline O. huetiana & 18.1 & 34.3 & 0.0 & 46.3 & 0.0 & 0.0 & 0.0 & 1.4 & 0.0 & 98.9 & 1.4 \\
\hline O. altissima & 1.7 & 0.0 & 95.3 & 1.9 & 0.0 & 0.7 & 0.4 & 0.0 & 0.0 & 98.4 & 1.2 \\
\hline O. hypargyrea & 5.8 & 0.0 & 23.8 & 3.3 & 65.7 & 0.0 & 0.0 & 0.0 & 1.5 & 33.0 & 65.6 \\
\hline
\end{tabular}

and tocochromanols may be a good chemotaxonomic criterion for this family, particularly with regard to the studied taxa. However, further studies are required to confirm the results obtained so far. The evaluation of fatty acids and tocochromanols in a wider range of species of the Fabaceae is suggested as a powerful tool that might contribute to characterize the chemotaxonomic and evolutionary relationships among the tribes and genera of Fabaceae.

\section{ACKNOWLEDGEMENTS}

The first author is grateful to the TUBITAK -DFG for the award of fellowship and research grants during the course of part of this investigation at Munster-Germany, and also is thankful to the Aegean Agricultural Research Institute, Izmir-Turkey.

\section{REFERENCES}

Aitzetmuller K. 1997. Vegatable oils of the world: Names of oils and fats and their botanical source. First Addendum. Fett-Lipid, 99, 302-303.

Akpinar N., Akpinar MA., Türkoglu S. 2001. Total lipid content and fatty acid composition of the seeds of some Vicia L. species, Food Chemistry, 74, 449-453

Anttolainen M., Valsta, L M., Rasanen L. 1995. Relationship between Vitamin E, beta carotene, energy, and saturation degree of dietary fats, Scand, $J$. Nutr., 39, 142-144.

Azcan N., Saricoban S., Demirci B., Aytac Z., Baser, KHC. 2001. Seed oils of fifteen Ebenus taxa growing in Turkey. Chemistry of Natural Compounds, 37, 253-255.

Bagci E., Bruehl, L., Aitzetmuller, K. and Altan Y. 2004. Fatty acid and tocochromanol patterns of some Turkish Boraginaceae. Nordic J. of Botany 22 (6), 719-726

Bagci E., Vural, M. 2001. Fatty acid composition of Astragalus pycnocephalus var. pycnocephalus and Astragalus condensatus, a chemotaxonomic approach. J. of the Inst. of Sci and Tech. of Gazi Univ., 14, 1305-1311.

Bagci E., Genç H., Sahin A. 2001. Fatty Acid composition of four Lathyrus aphaca L. varieties, a chemosystematic approach. Pakistan Journal of Biology. 4, 842-874.

Bagci E., Bruehl L., Aitzetmuller K., Altan Y. 2003. A chemotaxonomic approach on the fatty acid and tocochromanol content of Cannabis sativa $L$. (Cannabaceae). Tr. J.of Botany, 27, 141-147.

Bagci E., Sahin A. (2004). Fatty acid patterns of the seed oils of some Lathyrus L. (Papilionideae) from Turkey, a chemotaxonomic approach. Pakistan Journal of Botany. 36 (2), 403-413

Balogun AM., Fetuga BL. 1985. Fatty acid composition of seed oils some members of the Legumniosae family. Food Chemistry, 17, 175-182.

Balz M., Schulte E., Thier HP. 1992. Trennung von tocopherolen und tocotrienolen durch HPLC, Fat Sci. Technol., 94, 209-213.

Baudet I. 1976. Use of meal from zero-erucic acid rapeseed in animal food. Fette Seifen Anstrichmittel. 78, 435-435.

Chowdurry AR., Banerjii R., Misra G., Nigam S.K. 1984. Studies on Leguminous seeds, J. Am. Oil Chem., Soc., 61, 1023-1024.

Chowdury AR., Tewari, SR., Banerji R., Misra G., Nigam S.K. 1986. Studies on Leguminous seeds, II. Fette Seifen Anstrichmittel, 88, 144-146.

Chowdury AR. Banerjii R. 1995. Studies on Leguminosae seeds. Fett Wissenschaft Technologie - Fat Science technology, 97, 457-458.

Daulatab CD., Hosamani KM., Deasi VA., Alagawadi KR. 1987. Cyclopropenoid fatty acids in Leguminosae Oils, JAOCS, 64, 1423. 
Davis PH. 1970. Flora of Turkey and The East Aegean Island, 3, Edinburgh University Press.

Davis PH. 1988. Flora of Turkey and The East Aegean Island, 10, Edinburgh University Press.

DGF - (1989), Einheitsmethoden, Wissenschaftliche Verlagsges. m.b.h., Stuttgart; Method C - VI 11 a (81).

Feil B., Stamp P. 1993. Sustainable agriculture and product quality - a case study for selected crops. Food Reviews International, 9, 361-388.

Freeman MP. 2000. Omega -3 fatty acids in psychiatry: a review. Ann. Clin Psychiatry, 12, 159-65.

Garcia- Lopez PM., Muzquiz MA., Lopez-Ruiz MA., Zamora-Natera JF., Burbano C., Pedrosa, MM. Cuadrado C., Garzón-De la Mora P. 2001. Chemical composition and Fatty Acid Profile of several Mexican wild Lupins, Journal of Food Composition and Analysis, 14, 645-651.

Goffman FD., Thies W., Velasco L. 1999. Chemotaxonomic value of tocopherols in Brassicaceae. Phytochemistry, 50, 793-798.

Grela ER., Gunter KD. 1995. Fatty acid composition and tocopherol content of some Legume seeds. Animal Feed Science and Technology, 52, 325-331.

Gunstone FD., Steward SR., Cornelius JA., Hammonds TW. 1972. New tropical seed oils . IV- Component acids of Leguminous and other seed oils including useful sources of crepenynic and dehydrocrepenynic acid. $J$. Sci. Fd. Agric., 23, 52-60.

Hamberg M., Fahlstadius P. 1992. On the specificity of a fatty acid epoxygenase in broad bean (Vicia faba L.). Plant Physiology, 99, 987-995.

Hemevathy J., Prabhakar JV. 1989. Lipid composition of Fenugreek (Trigonella foenum-graceaum L.) seeds. Food Chemistry, 31, 1-7.

Higuchi M, Terao J., Jwai K. 1982. Gas Chromatography-Mass spectrometric determination of fatty acid in seed oil of winged bean (Psophocarpus tetragonolobus (L.) DC. J. Of Nutritional Science and Vitaminology. 28, 511-518.

Hilditch TP., Williams PN. 1964. The chemical constituents of natural fats 4th ed. Chapman and Hall, London, 304-321.

Ivanov SA., Aitzetmuller K. 1998. Untersuchungen über die tocopherol-und-tocotrienol- Zusammensetzung der samenlipide einiger arten der Bulgarischen Flora. Fett.-Lipid, 100, 348-352.

James TN. 1994. The toxic oil syndrome, Clinical Cardiology 17 (9), 463-470.

Kleiman R. 1988. Genetic diversity of plant lipids in plant germplasm. Proceeding world conference on biotechnology for the fats and oils industry, (T.H., Applewhite ed.) 73-77.

Krishna AG., Prabhakar VS., Aitzetmuller K. 1997. Tocopherol and fatty acid composition of some Indian pulses. JAOCS, 74,12.

Liu K., Brown EA., Orthoefer F. 1995. Fatty acid composition within each structural part and section of a soybean seed. J. of Agricultural and Food Chemistry, 43, 381.

Mabberly DJ. 1997. The Plant Book. Cambridge University Press, Cambridge, 320-323.

Meydani SN., Lichtenstein AH., White PJ., Goodnight S.H. 1991. Food use and health effects of soybean and sunflower oils. J. Am. Coll. Nutr., 10, 406-28.

Sengupta A., Basu S. 1978. Trygliceride composition of Enteda phasolides seed oil. J. Am. Sci. Food. Agric. 29, 677-682.

Seçmen Ö., Gemici Y., Leblebici E., Görk G., Bekat L. 1989. Tohumlu Bitkiler Sistematigi, Ege Üniv. Fen Fak., Kitaplar Ser., 116.

Seher A., Ivanov S. 1973. Natural antioxidants I: antioxidative action of tocotrienols, Fette Seifen Anstrichm., 75, 606-608.

Tharib SM., Veitch GBA., (1983). The fatty acids of Phaselous coccineus and Gleditsia triacanthos (Family: Leguminosae). Int.J.Crude Drug. Res., 21, 73-77.

Tewatia BS., Virk AS. 1996. Nutritional potential of Faba bean for improved productivity in ruminants. FABIS-Newsletter, 38-39.

Tseveguren N., Aitzetmuller K., Otgonbayar O. 1998. Fatty acid patterns of the seed oils of some plants from Mongolia, Reports of the Institute of Chemistry and Chemical Technology, Ulaanbatar.15.

Ucciani E. 1995. Nouveau Dictionnaire des Huiles Vegatales (Compositions en acides grs.) Lavoisier Tec. and Doc. Paris.

Velasco L., Goffman F., Pujadas-Salva A J. 2000. Fatty acids and tocochromanols in seeds of Orobanche. Phytochemistry. 54, 295-300.

Wolff I A., Kwolek W F. 1971. Lipids of the Leguminosae, in Chemotaxonomy of the Leguminosae. In Harborne, J.B., Boulter, D., Turner, B.L. eds., 1971. Academic press, London and New York. 